\title{
Review on Control Methods against Plant Parasitic Nematodes Applied in Southern Member States (C Zone) of the European Union
}

\author{
Nicola Sasanelli ${ }^{1}$, Alena Konrat ${ }^{2}$, Varvara Migunova ${ }^{3, *}$, Ion Toderas ${ }^{4}$, Elena Iurcu-Straistaru ${ }^{4}$, Stefan Rusu ${ }^{4}$, \\ Alexei Bivol ${ }^{4}$, Cristina Andoni ${ }^{4}$ and Pasqua Veronico ${ }^{1}$ \\ 1 Institute for Sustainable Plant Protection, CNR, St. G. Amendola 122/D, 70126 Bari, Italy; \\ nicola.sasanelli@ipsp.cnr.it (N.S.); pasqua.veronico@ipsp.cnr.it (P.V.) \\ 2 Federal State Budget Scientific Institution "Federal Scientific Centre VIEV" (FSC VIEV) of RAS, \\ Bolshaya Cheryomushkinskaya 28, 117218 Moscow, Russia; alenakonrat@vniigis.ru \\ 3 A.N. Severtsov Institute of Ecology and Evolution, Russian Academy of Sciences, Leninsky Prospect 33, \\ 119071 Moscow, Russia \\ 4 Institute of Zoology, MECC, Str. Academiei 1, 2028 Chisinau, Moldova; iontoderas@yahoo.com (I.T.); \\ iurcuelena@mail.ru (E.I.-S.); rusus1974@yahoo.com (S.R.); bivolalexei65@gmail.com (A.B.); \\ andonicristina23@gmail.com (C.A.) \\ * Correspondence: varvara.migunova@sevin.ru
}

Citation: Sasanelli, N.; Konrat, A.; Migunova, V.; Toderas, I.; Iurcu-Straistaru, E.; Rusu, S.; Bivol, A.; Andoni, C.; Veronico, P. Review on Control Methods against Plant Parasitic Nematodes Applied in Southern Member States (C Zone) of the European Union. Agriculture 2021, 11,602. https://doi.org/10.3390/ agriculture11070602

Academic Editors: Sarah J. Pethybridge and Frank Hay

Received: 4 June 2021

Accepted: 24 June 2021

Published: 28 June 2021

Publisher's Note: MDPI stays neutral with regard to jurisdictional claims in published maps and institutional affiliations.

Copyright: (c) 2021 by the authors. Licensee MDPI, Basel, Switzerland. This article is an open access article distributed under the terms and conditions of the Creative Commons Attribution (CC BY) license (https:// creativecommons.org/licenses/by/ $4.0 /)$.

\begin{abstract}
The European legislative on the use of different control strategies against plant-parasitic nematodes, with particular reference to pesticides, is constantly evolving, sometimes causing confusion in the sector operators. This article highlights the nematode control management allowed in the C Zone of the European Union, which includes the use of chemical nematicides (both fumigant and non-fumigant), agronomic control strategies (crop rotations, biofumigation, cover crops, soil amendments), the physical method of soil solarization, the application of biopesticides (fungi, bacteria and their derivatives) and plant-derived formulations. The authors analyze the use of these strategies and substances in organic agriculture as well as in Integrated Pest Management (IPM) programs.
\end{abstract}

Keywords: biopesticides; chemicals; EU legislation; nematode control strategies; plant extracts

\section{Introduction}

Plant-parasitic nematodes (PPNs) can severely damage plants and cause significant yield losses to numerous vegetable crops [1-3]. The degree of plant growth impairment caused by PPNs may depend on the nematode species, physiological race and the initial nematode population density in the soil at sowing or transplanting. In the case of high levels of soil infestation (>64 eggs and juveniles/mL soil), they can completely destroy the crop as the plants may die [1]. They can interact with soilborne plant pathogens causing greater severity of symptoms (yellowing, stunting growth, wilting, dwarfism) of plant disease [4-6]. Seinhorst's equation $y=m+(1-m) \mathrm{z}^{(P-T)}$ describes the relationship between nematode population density and crops (Figure 1) [7,8]. Therefore, nematode control strategies are required to limit nematode population density to no-damage levels.

The latest European Legislations (Reg. (EU) 2005/396; 2007/1095; 2009/1107; 2016/2031; 2019/1702; 2019/2072; EC Directives 2009/127 and 128) have been deeply revised and restricted the use of pesticides on agricultural crops focusing attention on environmental safety, human and animal health. Plant protection strategies against PPNs, insects and soil-borne plant pathogens should therefore rely on alternative control measures that are both environmentally sound and economically sustainable. 


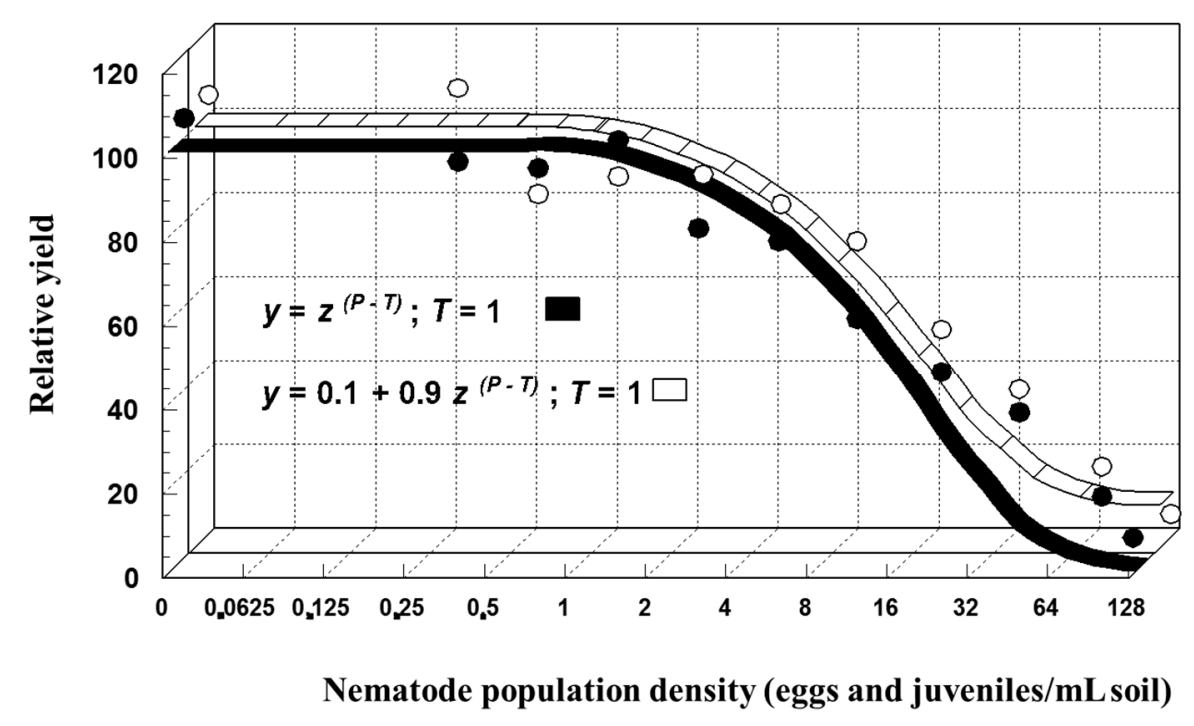

Figure 1. Relationship between plant growth [plant weight (black) and height (white)] and nematode population density in the soil represented by Seinhort's equation. In this equation, $y$ (relative yield) is the ratio of the yield at a given population density $P i$ to the yield in the absence of nematodes, $m$ is the minimum relative yield ( $y$ at very large $P i$ ), $z$ is a constant $<1$, where $z^{-T}=1.05$; $P i$ is the nematode population density at transplant or sowing and $T$ is the tolerance limit of the crop to the nematode ( $P i$ at which no yield is lost).

In the past, an effective nematode control was achieved by the use of methyl bromide (MB). The use of this product has been banned in advanced countries since 2005 because of stratospheric ozone depletion. After the ban on the use of MB and the revocation of 1 , 3-dichloropropene in European Union (EU) countries, the control strategies aim to reduce soil nematode population levels to below the tolerance threshold of the crop; they integrate chemical nematicides, bionematicides (mainly based on fungi or bacteria), physical methods (soil solarization, heating sterilization, ozone treatments) and/or agronomic practices (crop rotation, use of resistant varieties or nematicidal plants, anaerobic soil disinfection, green manures, biofumigation, soil amendments).

The registration process for pesticides in the EU starts with the active ingredient approval process which ends with a vote, after which, when positive, the active is listed in Annex 1 as approved. For the authorization of formulated products, after Annex 1 listing of active substances and their use, the EU is divided into three zones: A-North Europe (Denmark, Estonia, Finland, Latvia, Lithuania, Sweden), B-Central Europe (Austria, Belgium, Croatia, Czech Republic, Germany, Ireland, The Netherlands, Poland, Romania, Slovak Republic, Slovenia, Hungary) and C-South Europe (Bulgaria, Cyprus, France, Greece, Italy, Malta, Portugal and Spain) [Reg. (EU) 2009/1107]. The evaluation and approval of a pesticide or nematicide product can be done at a zonal level and later follows the national registrations in the countries of the zone. Considering that the European legislation on the use of pesticides is constantly evolving, sometimes causing confusion in sector operators, this paper reports the nematode control methods applied in the C Zone of the EU. These include the use of fumigants and systemic nematicides, agronomic and physical methods, biopesticides and plant extracts, omitting some of the most obvious techniques such as the use of resistant cultivars or the grafting of susceptible plants on resistant rootstocks.

\section{Fumigants}

These substances are phytotoxic and must be applied at least one month before sowing or transplanting. They are precursors of methyl isothiocyanate (MITC). The fumigants with nematicidal action are highly volatile; when applied to the soil, they evaporate and, in the gaseous state, fill the empty spaces of the soil. As they diffuse into the atmosphere in 
considerable quantities, it is necessary to cover the soil surface with plastic film in order to retain the gaseous molecules which will improve the efficacy of the treatment, reducing environmental harm [9].

\subsection{Metam-Sodium}

Metam sodium $\left(\mathrm{C}_{2} \mathrm{H}_{4} \mathrm{NNaS}_{2}-\mathrm{CAS}\right.$ No. $\left.137-32-8-\mathrm{Metam}-\mathrm{Na}\right)$ is a synthetic chemical product in liquid formulation with a fumigant action, applicable to the soil by sprinkler or drip irrigation or by direct injection through an injector pole for small surfaces, and with a device connected to a tractor for open field treatments. However, many trials have demonstrated its higher efficacy against root-knot and cyst nematodes, when applied by shank injection, than through the use of a sprinkler irrigation system [8,9]. The product kills nematodes by different action modes affecting enzymatic, respiratory and nervous systems $[10,11]$. Its lethal dose fifty $\left(\mathrm{LD}_{50}\right)$ for mammals (rat) by oral administration is $896 \mathrm{mg} / \mathrm{kg}$ [12]. The maximum residue limits (MRLs) are 50, 30 and $20 \mu \mathrm{g} / \mathrm{Kg}$ on lettuce, tomato and other vegetables, respectively. It is recommended that it is applied to the soil at a temperature between 10 and $30^{\circ} \mathrm{C}$ (optimal is $20^{\circ} \mathrm{C}$ ), with doses ranging between 400 and $1500 \mathrm{~L} / \mathrm{ha}$, depending on the pest to control. The product, in addition to the nematicidal action, has also herbicidal, insecticidal and fungicidal efficacy [13-15]. As a result of Metam sodium hydrolysis appears MITC with biocidal activity. To avoid the release of the active ingredient MITC into the atmosphere, and to improve biocidal efficacy, it is better to cover the treated soil with a $0.03 \mathrm{~mm}$ thick polyethylene plastic film. The covering duration (3-6 weeks) depends on temperature. After the fumigation, it is necessary to remove the plastic film to allow aeration of the soil (at least 1 week) to avoid a phytotoxic effect on the crop at transplant or sowing. The product can be applied both in the open field and to plastic-protected crops where the greenhouse effect can improve the efficacy of the product by heat synergy effect. It can be used on the same soil every three years [16]. Besides the countries of the C Zone of the EU, its use is also allowed in Belgium, Hungary, Ireland, The Netherlands and Poland, according to the Pesticide Properties DataBase (PPDB) [12]. Date EC 2009/1107 inclusion expire is 30 June 2022 [12]. On the contrary, its use has been banned since autumn 2018 in France by the ANSES (the National Health Security Agency) due to the respiratory intoxications of some vegetable producers in western France. The product also cannot be used in Bulgaria, Malta and Spain (Table 1).

\subsection{Metam-Potassium}

The product $\left(\mathrm{C}_{2} \mathrm{H}_{4} \mathrm{KNS}_{2}\right.$-CAS No. 144-54-7-Metam-K), similarly to Metam-Na, has nematicidal, herbicidal, insecticidal and fungicidal activities and the same action mode [17]. Its $\mathrm{LD}_{50}$ for mammals (rabbit) by oral administration is $630 \mathrm{mg} / \mathrm{kg}$, which is lower than that shown for metam-Na on rats [12]. The commercial products contain about $42 \%$ of pure metam-K. Unlike Metam-Na, it releases $\mathrm{K}^{+}$cations into the soil resulting in greater availability of this element for plants. It is applied in lower doses than Metam-Na ranging between $500-750 \mathrm{~L} / \mathrm{ha}$, according to the pest to control. The use of the product is allowed only in Italy and Greece (Table 1). 
Table 1. Availability of active substances approved as nematicide products in the Southern zone of the European Union (31 May 2021).

\begin{tabular}{|c|c|c|c|c|c|c|c|c|c|c|c|c|c|c|c|c|}
\hline \multirow{2}{*}{ Nematicide Actives } & \multicolumn{2}{|c|}{ Bulgaria } & \multicolumn{2}{|c|}{ Cyprus } & \multicolumn{2}{|c|}{ France } & \multicolumn{2}{|c|}{ Greece } & \multicolumn{2}{|c|}{ Italy } & \multicolumn{2}{|c|}{ Malta } & \multicolumn{2}{|c|}{ Portugal } & \multicolumn{2}{|c|}{ Spain } \\
\hline & PC* & $\mathrm{OF}^{* *}$ & PC & OF & PC & OF & PC & OF & PC & OF & PC & OF & PC & OF & PC & OF \\
\hline Dazomet & Yes & Yes & - & - & - & - & Yes & Yes & Yes & Yes & - & - & Yes & Yes & - & 一 \\
\hline Metam sodium & - & - & Yes & Yes & - & - & Yes & Yes & Yes & Yes & - & - & Yes & Yes & - & - \\
\hline Fluopyram & Yes & Yes & Yes & Yes & Yes & Yes & Yes & Yes & Yes & Yes & - & - & Yes & Yes & Yes & Yes \\
\hline Fosthiazate & Yes & Yes & Yes & Yes & - & Yes & Yes & Yes & Yes & Yes & - & - & - & - & Yes & Yes \\
\hline Oxamyl & Yes & Yes & Yes & Yes & - & Yes & Yes & Yes & Yes & Yes & Yes & Yes & Yes & Yes & Yes & Yes \\
\hline Abamectin & Yes & $x$ & Yes & $x$ & - & - & Yes & - & Yes & - & - & - & - & - & Yes & 一 \\
\hline Azadiractin & - & - & - & - & - & - & - & - & Yes & - & - & - & - & - & - & - \\
\hline Bacillus firmus I-1582 & Yes & Yes & - & - & Yes & Yes & Yes & Yes & Yes & Yes & - & - & Yes & Yes & Yes & Yes \\
\hline Garlic extract & Yes & Yes & Yes & Yes & Yes & Yes & Yes & Yes & Yes & Yes & - & - & Yes & Yes & Yes & Yes \\
\hline $\begin{array}{l}\text { Purpureocili. lilacinum } \\
\text { strain } 251\end{array}$ & - & - & Yes & Yes & Yes & Yes & Yes & Yes & Yes & Yes & - & - & Yes & Yes & Yes & Yes \\
\hline
\end{tabular}

${ }^{*}$ PC $=$ Protected crops; ${ }^{* *}$ OP = Open field; Yes = approved active substance included in the Annex 1 of the EU Reg. 2009/1107; - = not approved. 


\subsection{Dazomet}

The fumigant $\left(\mathrm{C}_{5} \mathrm{H}_{10} \mathrm{~N}_{2} \mathrm{~S}_{2}\right.$-CAS No. 533-74-4) is a granular product easy to apply to the soil because it can be spread as a normal fertilizer. After its application, it must be incorporated into the soil by a rotovator. The treatment is completed by irrigation to ensure the chemical transformation of the product into MITC, formaldehyde and carbonyl sulphide, which provide pest control. As with the previous fumigants, it is necessary to cover the soil surface with an impermeable plastic film (VIF) to avoid MITC aerial dispersion in the environment. The product can be applied both in the open field and to protected crops using a rate variable between 500 and $700 \mathrm{Kg} / \mathrm{ha}$ according to the pest species and the soil nematode population density. The interval between chemical treatment and planting or sowing of the crop may vary significantly; from 2 to 5 weeks, depending on temperature, humidity and soil type. It is not recommended to apply it below $10^{\circ} \mathrm{C}$. The phytotoxicity of the product does not allow its distribution in the presence of the crop. In addition to the nematicidal activity, Dazomet has also a fungicidal effect [18]. Its mammal acute oral $\mathrm{LD}_{50}(415 \mathrm{mg} / \mathrm{Kg})$ is lower than those for metam-sodium and metam-potassium as it shows higher toxicity compared to these products [12]. The maximum food residue limit is $20 \mu \mathrm{g} / \mathrm{Kg}$. The use of the product against PPNs (root-knot and cyst nematodes) allows a significant reduction of soil nematode population densities. This improves the yields of the treated crops, their quality and quantity $[19,20]$. The use of Dazomet is allowed for the C Zone of EU only in Bulgaria, Greece, Italy and Portugal (Table 1).

\section{Non-Fumigant Products}

These chemical compounds with very low phytotoxicity can be used at transplanting or sowing and during the crop cycle. Such formulations belong to phosphorganic compounds, carbamates, benzamides and avermectins which have different mechanisms of action to cause nematode death. They are available on the market in granular, liquid and microencapsulated formulations.

\subsection{Fenamiphos}

Fenamiphos is an inhibitor of organophosphate acetylcholinesterase. It is used as insecticide and nematicide $\left(\mathrm{C}_{13} \mathrm{H}_{22} \mathrm{NO}_{3} \mathrm{PS}-\mathrm{CAS}\right.$ No. 22224-92-6). The product is highly toxic via the oral route with reported $\mathrm{LD}_{50}$ values of 2 to $19 \mathrm{mg} / \mathrm{kg}$ in the rat and 56 to $100 \mathrm{mg} / \mathrm{kg}$ in guinea pigs [12]. It is a systemic product rapidly adsorbed into plants [21,22]. It is effective against semi- and endoparasites both of epigeal (Aphelenchoides spp., Ditylenchus spp.) and hypogeal (Meloidogyne spp., Globodera spp., Heterodera spp.) parts of the plant. On the market, a microencapsulated formulation ( $240 \mathrm{~g} / \mathrm{L} \mathrm{CS})$ is also available for use in protected crops on vegetables (tomato, eggplant, pepper, cantaloupe, melon, cucumber and squash) or ornamental plants. It can be applied one day before transplanting at the rate of $42 \mathrm{~L} /$ ha by PVC drip irrigation lines [23]. In the soil, it is oxidized to its sulfoxide and sulphone metabolites, which are also toxic to PPNs. Fenamiphos affects several biological processes, among them juvenile orientation (through their chemoreceptors responding to root exudates), egg hatch (inside egg masses or cysts) and the infectivity of the second juvenile stages. The preharvest interval is 60 days due to its high toxicity. The MRL of fenamiphos is $20 \mu \mathrm{g} / \mathrm{Kg}$ of vegetables and fruits.

However, the product is actually revoked due to failure to renew the approval pursuant to Implementing Regulation (EU) N ${ }^{\circ} 2020 / 1246$ of the Commission (the use of the revoked product is allowed until 23 September 2021 in Italy).

\subsection{Fosthiazate}

Fosthiazate is a systemic nematicide and insecticide $\left(\mathrm{C}_{9} \mathrm{H}_{18} \mathrm{NO}_{3} \mathrm{PS}_{2}-\mathrm{CAS}\right.$ No. $98886-$ 44-3) that provides effective control of root-knot, root lesion, cyst and free-living nematodes in a wide range of crops. It has an acute oral $\mathrm{LD}_{50}$ value of $57 \mathrm{mg} / \mathrm{Kg}$ on rats [12]. It acts by contact and ingestion in low concentration or dose. It is an inhibitor of acetylcholine esterase. It is available as granular or liquid formulations. The granular formulation is 
spread on the soil surface and then incorporated into the soil to control Meloidogyne spp., Globodera spp., Heterodera spp. and Pratylenchus spp. The liquid formulation is applied in chemo-irrigation. In addition to nematode control, it is also effective against aphids, mites and thrips in vegetables. It is used at the rate of $3 \mathrm{Kg}$ of active ingredient (a.i.)/ha. It is registered for tomato and potato on which MRL is $20 \mu \mathrm{g} / \mathrm{kg}$. It can be applied only before transplanting or sowing [24]. Its use is allowed in all countries of the Southern EU with the exception of Malta and Portugal, and in France on protected crops (Table 1).

\subsection{Oxamyl}

Oxamyl is a carbamate pesticide $\left(\mathrm{C}_{7} \mathrm{H}_{13} \mathrm{~N}_{3} \mathrm{O}_{3} \mathrm{~S}-\mathrm{CAS}\right.$ No. 23135-22-0). The liquid formulation has a slightly sulfurous odor with a relatively low $\operatorname{LD}_{50}(5.4 \mathrm{mg} / \mathrm{kg})[12,25]$. Despite its high toxicity, it is rather popular because of its rapid degradation in the soil: the oxamyl half-life $\left(\mathrm{DT}_{50}\right)$ ranges from a few hours to a few days [26,27]. It is systemic in the plants and highly soluble in water [28]. For these reasons, it is applied through PVC drip irrigation lines allowing a reduction in production costs. Before its application, the product must be acidified by ortho-phosphoric acid; in the soil, it is rapidly degraded by hydrolytic processes. The acidification must be close to $\mathrm{pH} 4.5$ to improve the absorption and the availability for root systems of the active ingredient. The $\mathrm{pH}$ value influences the degradation speed of the product (at pH 9, oxamyl is no longer found after $48 \mathrm{~h}$ ) [27]. It is effective in the control of root-knot and cysts nematodes. It acts on mobile forms and eggs. It is also an insecticide acting on insects with stinging sucking apparatus. It is used at variable rates according to the crop and label instructions. It is allowed on tomato, pepper, eggplant, melon, tobacco, cucumber and squash with an MRL value of $10 \mu \mathrm{g} / \mathrm{kg}$ [12]. Treatments are carried out one day before transplanting or sowing and they can be repeated every 15 days with a maximum of 2 applications for cucumber and squash, 4 for tomato and pepper and 5 for melon The postharvest interval is 14-28 days according to the crop [29]. It can be used in all countries excluding France on protected crops (Table 1).

\subsection{Fluopyram}

It is a systemic fungicide that also has a nematicidal effect $\left(\mathrm{C}_{16} \mathrm{H}_{11} \mathrm{ClF}_{6} \mathrm{~N}_{2} \mathrm{O}-\mathrm{CAS}\right.$ No. 658066-35-4). The product is characterized by low toxicity to vertebrates and invertebrates. The acute $\mathrm{LD}_{50}$ is higher than $2000 \mathrm{mg} / \mathrm{Kg}$ for rats (oral administration), indicating its safety compared to other nematicides [12]. Low and moderate toxicity has been demonstrated to bees and fish, respectively [30]. In the EU, values of 0.5 and $0.15 \mu \mathrm{g} / \mathrm{Kg}$ are MRLs for tomato and potato, respectively [12]. The compound inhibits the complex II (succinate-ubiquinone reductase) involved in mitochondrial respiration [31]. The product has an inhibiting effect on juveniles hatching from eggs of Meloidogyne spp. and cysts of Globodera spp. and Heterodera spp. [32,33]. The product is also effective against the stem bulb nematode Dytilenchus dipsaci on sugar beet [34]. It is effective against gray mold (Botrytis cinerea), powdery mildew (Sphaerotheca fuliginea and Erysiphe cichoracearum), apple scab (Venturia inaequalis), early blight (Alternaria solani), white mold (Sclerotinia sclerotiorum) and brown rot (Monilinia laxa). Due to its nematicidal and fungicidal activity, this product can be used against fungal diseases and simultaneous PPNs attacks. In this case, treatments are different considering that the mentioned fungal diseases concern the aereal part of plants and the nematode attack affects their root systems. In the USA, Fluopyram has also been used as a seed treatment to protect soybean plants at the early developing stage from several nematodes (Heterodera glycines, M. incognita, Rotylenchulus reniformis, Pratylenchus spp., and Hoplolaimus spp.) and soil-borne plant pathogens (Fusarium virguliforme and Septoria glycines) [35-40].

It is a liquid formulation and therefore applied on protected horticultural crops by chemo irrigation in pre (1-3 days) and post-transplant (15-30 days later) at the dose of $0.4-0.6 \mathrm{~L} / \mathrm{ha}$ with a water volume of 2000-6000 L/ha [41]. In open field conditions, it is better to use the highest dose according to the product label. It is allowed for carrot, 
cucumber, tomato, eggplant, melon, pepper, potato, squash and tobacco. Its use is allowed by EU legislation until 31 January 2024. It is not possible to use it in Malta.

Table 2 reports types of synthetic nematicides (fumigant and non-fumigant) and their main characteristics; formulation, a.i. concentration, application time and rate.

Table 2. Fumigants and non-fumigants authorized in the C Zone of the EU against plant-parasitic nematodes (approved for use under EC Reg. 2009/1107 according to PPDB: Pesticide Properties Data Base).

\begin{tabular}{|c|c|c|c|c|c|c|}
\hline $\begin{array}{c}\text { Type of } \\
\text { Nematicide }\end{array}$ & Name & Formulation & $\begin{array}{c}\text { Concentration a.i. }{ }^{1} \\
(\mathrm{~g} / \mathrm{L} \text { or } \mathrm{g} / \mathrm{Kg})\end{array}$ & Application Time & $\begin{array}{c}\text { Dose } \\
\text { (L or } \mathrm{Kg} / \mathrm{ha})\end{array}$ & $\begin{array}{l}\text { Covering with } \\
\text { Plastic Film }\end{array}$ \\
\hline \multirow{3}{*}{ Fumigant } & $\begin{array}{c}\text { Metam } \\
\mathrm{Na}^{2}\end{array}$ & Liquid & 500 & $\begin{array}{l}\text { Pre- transplant or } \\
\text { sowing }\end{array}$ & $400-1500$ & Yes \\
\hline & $\begin{array}{l}\text { Metam } \\
\mathrm{K}^{3}\end{array}$ & Liquid & 500 & $\begin{array}{l}\text { Pre- transplant or } \\
\text { sowing }\end{array}$ & $400-750$ & Yes \\
\hline & Dazomet & Granular & 990 & $\begin{array}{l}\text { Pre- transplant or } \\
\text { sowing }\end{array}$ & $500-700$ & Yes \\
\hline \multirow{4}{*}{ Non-fumigant } & Fenamiphos ${ }^{4}$ & Microencapsulated & 240 & $\begin{array}{l}\text { At transplant or } \\
\text { sowing }\end{array}$ & 42 & No \\
\hline & Fosthiazate ${ }^{5}$ & $\begin{array}{l}\text { Granular (GR) or } \\
\text { liquid (Lq) }\end{array}$ & $\begin{array}{l}\text { GR-100 } \\
\text { Lq-150 }\end{array}$ & $\begin{array}{l}\text { At transplant or } \\
\text { sowing }\end{array}$ & $\begin{array}{c}\text { GR-30 } \\
\text { Lq-10 }\end{array}$ & No \\
\hline & Oxamyl & Liquid & 100 & $\begin{array}{c}\text { At transplant or } \\
\text { sowing and during } \\
\text { crop cycle }\end{array}$ & $10-20$ & No \\
\hline & Fluopyram & Liquid & 400 & $\begin{array}{c}\text { Pre- and } \\
\text { post-transplant }\end{array}$ & $0.4-0.6$ & No \\
\hline
\end{tabular}

1 a.i. = active ingredient; ${ }^{2-3}$ their use has been banned since autumn 2018 in France by ANSES (National Health Security Agency), moreover they cannot be used in Bulgaria, Malta and Spain; ${ }^{4}$ the product is revoked due to failure to renew the approval pursuant to Implementing Regulation (EU) $N^{\circ} 2020 / 1246$ of the Commission (the use of the revoked product is allowed until 23 September 2021 in Italy); ${ }^{5}$ not allowed in Malta, Portugal and on protected crops in France. Note: It is important to follow the instructions reported on the label product as they differ according to pest and crop. Information on concentration, application times, doses and number of applications are reported on the label of each commercial product.

The chemical control of PPNs has the advantage of prompt efficacy and protection, it offers the possibility of several uses and application methods in different conditions, such as infestation levels. From an operational point of view, it is the simplest tool of nematode control, it is the only realistically usable means in the event of sudden emergencies, although this solution is far away from sustainable crop production [42].

On the contrary, the massive introduction of various xenobiotic substances (unrelated to biological processes) causes negative effects on the environment and on organisms not directly targeted by nematicides. Consumers could risk receiving plant products with higher pesticide residues (if growers try to increase the nematicide efficacy increasing applied doses), an emergence of resistant species, damage to non-target species (prolonged use causes toxicity phenomena on the micro, meso and macro-fauna), as well as risks and dangers for users and the environment [43].

\section{Agronomic Methods}

\subsection{Crop Rotations}

Crop rotation is the oldest technique aimed at limiting the damage caused by pests (PPNs) and preventing nutrient depletion. The practice consists of the following: a series of different types of crops are grown in the same area, in soil infested by a specific pest or PPN; host crops and non-susceptible crops are alternated in order to naturally reduce the populations of the pest to harmless levels [44].

Monocropping is the growth of the same crop in the same place for many years. This practice gradually depletes the soil of specific nutrients and causes the selection of highly competitive weeds and pests. Conversely, an effective crop rotation decreases the need for synthetic herbicides and fertilizers. Moreover, crop rotation improves the soil structure and raises organic matter content, reducing erosion and increasing the farm system's resilience. 
This technique is difficult to apply on polyphagous nematodes (i.e., Meloidogyne spp.) that multiply on different crops in rotation and sometimes also on weeds [45]. On the contrary, effective results are obtained on nematodes with specific host plants such as cysts nematodes (Globodera spp. and Heterodera spp.). Studies carried out in California (USA) on the effect of a crop rotation program on the beet cyst nematode $H$. schachtii soil population density have demonstrated that the level of the population decreased with the cultivation of non-host crops such as lettuce or tomato or when the land was fallow [46]. Other investigations on Triticum durum grown in soil infested by Heterodera avenae, Meloidogyne artiellia and Pratylenchus neglectus have shown the importance of biennial or four years crop rotations with melon, potato, tomato, sugar beet and corn to obtain decreases of these nematode populations and a significant increase of durum wheat yield [47]. However, it is important to point out that the populations of the root-knot nematodes decrease rapidly, up to $85 \%$ per year (1-2 years), while those of cyst nematodes demonstrate a slow decline, with an annual $25-64 \%$ reduction (3-8 years) [47]. The biomass of bacteria and fungi is strongly enhanced in crop rotation and no-tillage treatments resulting in a negative effect on PPNs [47].

\subsection{Biofumigation}

Biofumigation is a technique that consists of the use of green manure material which is incorporated into the soil in order to reduce the population of a parasite and increase soil fertility [48]. Many plants belonging to Capparales order (Brassicaceae, Tovariacerae, Resedaceae and Capparaceae families) contain glucosinolates which, by hydrolysis, in the presence of water in the soil and the enzyme myrosinase, release isothiocyanates and nitriles, toxic compounds with a broad biocidal spectrum of action [49-52]. These compounds have high biological activity against bacteria, soil-borne pathogens, insects, PPNs and inhibit weed seeds germination. Isothiocyanates are highly toxic volatile compounds and their effectiveness depends on many factors including $\mathrm{pH}$, temperature and soil humidity. The biocidal activity of some synthetic nematicides, such as Metam-sodium, is based on the release of isothiocyanates and specifically MITC. It is important to select species and cultivars to use as biocidal plants and cover crops, as well as flours and pellets obtained from protein panels of de-oiled seeds to be distributed in field or greenhouse for plant protection [53]. Studies carried out on the root-knot nematode Meloidogyne incognita demonstrated the efficacy of Brassica napus var oleifera cv. Reston, B. rapa cv. PI 226505, Crambe abyssinica cv. Hispanica 608 and Raphanus sativus cv. Pegletta in the control of the nematode reducing its reproduction factor $r$ below $1(r=P f / P i$ where $P f$ and $P i$ are the final and initial nematode population density, respectively) [52]. The most common glucosinolates are sinigrin (in B. carinata, B. napus, B. juncea), erucin (in Eruca sativa), sinalbin (in Sinapsis alba), glucoraphenin (in R. sativus, Rapistrum rugosum), glucotropaeolin (in B. hirta and Lepidium sativum) and gluconaturtiin (B. juncea, B. hirta, Barbarea verna) $[53,54]$. Biofumigation can be enhanced by covering the soil with impermeable plastic films that retain volatile toxic compounds. Biofumigation can be also combined with soil solarization. A more recent development is the formulations of concentrated emulsions containing vegetable glucosinolates [55]. These formulations, which can be used as soil amendments, allow the distribution of the product by PVC drip lines in fertirrigation, affecting the soil in which plants' roots are growing.

\subsection{Cover Crops}

Cover crops are used to conserve and increase the physical, chemical and microbiological soil fertility and reduce PPN populations by different mechanisms of action. They can act as (i) non-host or low susceptible crops that do not allow PPNs to complete their life cycle, (ii) producers of secondary "allelochemical" metabolites that affect nematode population and (iii) factors creating favorable conditions for the development of microflora and microfauna antagonists of PPNs [56]. 


\subsection{Fallow}

In the areas with intensive agriculture, this technique is certainly not sustainable as the field is left without plants on which nematodes feed. It causes the PPN's death owing to the lack of food. The results are better if the fallow period is complemented with weeding. The duration of the fallow period depends on the rates at which the PPN populations decrease [54].

\subsection{Trap Crops}

This agronomic method consists of planting a host crop (carrot, cauliflower, mustard, potato, tomato and recently also rice) of sedentary plant-parasitic nematodes that use this crop for their feeding and multiplication. After juvenile penetrations, the developed females are unable to leave the roots and the trap crop is destroyed before egg-laying by nematodes has begun, trapping the nematodes in the root, avoiding their spread and reducing damage to the following crops [56,57].

\subsection{Soil Amendments}

The use of organic soil amendments is a traditional agricultural practice for improving physical and chemical soil properties, soil structure, temperature and humidity conditions as well as the nutrient content necessary for plant growth. The EU legislation on the use of soil amendments has been recently enacted by the "Commission Implementing Regulation" $\mathrm{N}^{\circ} 2164 / 2019$ [58]. The most important soil amendments reported are:

- farmyard manure (a mixture of animal excrements and vegetable matter, animal bedding);

- dried farmyard manure and dehydrated poultry manure;

- composted or fermented mixture of household waste;

- $\quad$ peat (use limited to horticulture, i.e., market gardening, floriculture, arboriculture, nursery);

- vermicompost and dejecta of insects;

- mollusc waste and chitin (both only from sustainable fisheries);

- Biochar, pyrolysis products made from a wide variety of organic materials of plant origin and applied as a soil conditioner (only from plant materials, untreated or treated with products included in Annex II) [56].

The suppressive effect of organic amendments of different origins and types is well documented against different PPNs (root-knot nematodes, cyst nematodes, root lesion and stem nematodes and the dagger nematodes) [59-67].

The mechanisms of the nematicidal action of soil amendments incorporated into the topsoil $(0-30 \mathrm{~cm})$ are different. The addition of soil amendments improve chemical and physical soil characteristic including soil total and organic nitrogen [66]. Mainly the nematicidal action can be ascribed to the release of ammonia, polyphenols and fatty acids from nitrogen sources by soil microorganisms, as reported by several authors $[65,68]$. Sometimes, the addition of soil amendments can promote the development of enzymes produced by fungi (chitinase, collagenase, Kerastase and elastase) which disintegrate nematode cuticles $[69,70]$.

The combination of the use of soil amendments with anaerobic soil disinfestation (ASD) is not very widespread in the Southern European countries, due to limited water availability. Anaerobic soil disinfestation requires, after the incorporation of soil amendments in the topsoil $(0-30 \mathrm{~cm})$, that the field be compacted and irrigated. The field is then mechanically covered with impermeable plastic films (VIF) to restrict oxygen supply to the topsoil. The soil is left covered for four/six weeks in the summer in which anaerobic conditions develop rapidly toxic fermentations responsible for the elimination of fungal, bacterial pathogens as well as insects, weeds and PPNs [71].

\section{Physical Methods}

In protected cropping systems or intensive field crops with continuous monocultures, farmers often apply physical soil disinfestation by steam or hot water. These measures, as 
well as microwave soil radiation, are expensive, whereas soil solarization is cheaper, more friendly to the environment and therefore more popular, especially in warm areas [72].

\section{Soil Solarisation}

Soil solarization is an environmentally friendly technique based on the increase of soil temperature using the sun's power and the application of plastic films. This technique helps to control bacteria, weeds, fungi, mites, insects and PPNs. Its effectiveness against PPNs was first demonstrated in Israel [73,74] and later in Australia [75], USA [76,77], Italy [78] and South Africa [79]. The efficacy of soil solarization is based on the sensitivity of PPNs to relatively high temperatures. The technique is effective against root-knot nematodes (Meloidogyne spp.) especially in plastic houses where soil temperatures in the top $30 \mathrm{~cm}$ of mulched soil can be $3-5{ }^{\circ} \mathrm{C}$ higher than those in mulched soil in open field conditions, thus causing higher nematode mortality [80]. Interesting results are also obtained against cysts nematodes (Globodera rostochiensis, G. pallida, Heterodera carotae and H. schachtii) [81-84], stem bulb nematodes (D. dipsaci), and reniform and root lesion nematodes (Rotylenchus reniform and Pratylenchus spp.) [85]. To obtain better results, it is useful to apply preventive soil irrigation which contributes to the optimum field capacity. After 3-4 days the soil is plowed by rotavator and then covered by a 30-50 $\mu \mathrm{m}$ plastic film (PE, LDPE, PVC or EVA) closing the plastic film laterally. Soil solarization time can range between 4 to 8 weeks depending on solar irradiation and its intensity (the best period is between June and August), geographical area and the type of soil. At the depth of $30-40 \mathrm{~cm}$, the temperature can range between 38 and $52{ }^{\circ} \mathrm{C}$. Devitalization of cyst nematode eggs requires higher soil temperature than that of eggs of Meloidogyne spp. because they are protected in the cysts. The efficacy of solarization to control PPNs is related to the soil temperature and the time of exposure to sun irradiation [86]. The technique can be combined with other agronomic methods such as the use of soil amendments [87] or biofumigation [88] or anaerobic soil disinfestation [89].

\section{Biopesticides (Fungi, Bacteria and Bacteria Derived Product) \\ 6.1. Fungi \\ 6.1.1. Purpureocillium lilacinum Strain 251}

The development of sustainable agricultural activities requires new production tools including biopesticides. The fungus Purpureocillium lilacinum produces proteolytic enzymes (protease and chitinase) which can destroy the shell of nematode eggs of many PPNs (Meloidogyne spp., Globodera spp. and Heterodera spp.) [90]. In the European Union, the strain PL251 which is effective against Rotylenchulus reniformis has been commercialized [91]. It is a liquid formulation; the germinated spores of the fungus develop and attack nematode eggs and other static forms. Furthermore, the fungus stimulates the production of substances (indolacetic acid, cytokinins, 1-aminocyclopropane- 1-carboxylate deaminase and citric acid) that promote plant growth. This commercial formulation contains $216 \mathrm{~g} / \mathrm{L}$, which corresponds to $5.1 \times 10^{13} \mathrm{CFU} / \mathrm{L}$. The recommended dose at transplant or in posttransplant is $0.75 \mathrm{~L} /$ ha with a volume of water of 3000-6000 L/ha on tomato, zucchini, pepper, melon, eggplant, onion, cucumber, garlic and artichoke. During the crop cycle, 3-4 applications are possible, depending on the infestation level [92]. The use of the fungus is not allowed in Bulgaria and Malta (Table 1).

\subsubsection{Pochonia clamydosporia}

Pochonia clamydosporia is a nematophagous hyphomycete used for PPNs control. It is approved as biostimulant although it has nematicidal properties. Therefore, it can be considered a potential nematicide to be approved. It is a parasitic fungus producing enzymes that destroy the eggshells of different PPNs' genera [93,94]. Moreover, P. chlamydosporia is also a root endophyte, improving growth of host plant species and their mechanisms of defense against different plant pathogens [95,96]. The commercial formulation contains $10^{8} \mathrm{CFU} / \mathrm{g}$ in combination with Arthrobotrys oligospora and mycorrhiza of the genus 
Glomus sp. It is allowed in organic farming and can be applied 2-3 times during the crop cycle, at the rate of $2 \mathrm{~L} / \mathrm{ha}$, both in open field and protected conditions through irrigation systems, to reduce production costs [97]. The product can also be used for root dipping seedlings to transplant.

\subsection{Bacteria and Bacteria Derived Product}

\subsubsection{Pasteuria penetrans}

It is an endospore-forming bacterium obligate parasite of Meloidogyne spp. [98]. Different nematode genera have been found worldwide in association with distinct species of Pasteuria. For every plant-parasitic nematode there is potentially a specific and adapted isolate of Pasteuria. In addition to P. penetrans, there are two other important species of Pasteuria that infect plant-parasitic nematodes: P. thorneii that infect the lesion nematodes Pratylenchus spp. [99] and P. nishizawae that is a parasite of the soybean cyst nematode Heterodera glycines [100]. The isolate Pn1 of P. nishizawae has been recently approved (2018) in the Annex 1 by the European Food Safety Agency (EFSA) by the rapporteur Member State Denmark for its use [101]. It is largely used in USA, Canada and Brazil with the commercial name Clariva $^{\mathrm{TM}}$ (Syngenta). The spores of the bacterium adhere to the nematode cuticle infecting the nematode. The endospore develops a germination tube that pierces through the cuticle and forms mycelia and microcolonies within the nematode's body causing nematode death. P. penetrans is a Gram + bacterium, not registered but in an advanced state of evaluation by the EU phytosanitary commission.

\subsubsection{Bacillus firmus}

It is a Gram + bacterium used as a biological nematicide for control of PPNs. The specific strain I-1582 has been selected for its nematicidal and plant health activities [102,103]. It is available in a wettable powder (WP $5 \%, 3.55 \times 10^{12} \mathrm{CFU} / \mathrm{Kg}$ c.p.) and applied at the rate of $80 \mathrm{Kg} / \mathrm{ha}$ before sowing/transplant or $40+40 \mathrm{Kg} /$ ha before and after sowing/transplant, respectively, and exempt from residue tolerance [104]. It is very much in line with IPM practices and does not affect beneficial insects when used according to the label of the commercial product and has no post-harvest interval. Its use is also allowed in organic farming [105]. The product has two effects, direct and indirect. The direct activity of the $B$. firmus is represented by the production of chitinolytic enzymes that degrade the egg shells causing devitalization of eggs and/or larvae inside the eggs. The indirect impact involves: (i) colonization of the host root surface, forming a physical barrier; (ii) degradation of root exudates disorienting nematodes movements so reducing root penetration; and (iii) stimulation of plant growth through production of phytohormones [103]. The commercial product is authorized for use on carrot, tomato, melon, cucumber, pepper, tobacco, watermelon, zucchini, eggplant and pumpkin in all Southern countries of Europe with the exception of Cyprus and Malta (Table 1) [104].

\subsubsection{Abamectin}

It is a mixture of macrocyclic lactons [avermectin B1a (80\%) and B1b (20\%)] with high biological activity. Abamectin is an anthelmintic agent, produced by Streptomyces avermitilis $\left[\mathrm{C}_{48} \mathrm{H}_{72} \mathrm{O}_{14}\right.$ (B1a), $\left.\mathrm{C}_{47} \mathrm{H}_{70} \mathrm{O}_{14}(\mathrm{~B} 1 \mathrm{~b})\right]$. It blocks $\gamma$-amino butyric acid by stimulating chloride channels, which leads to the opening of chloride channels not dependent on neurotransmitters [106]. This causes an ionic imbalance in the nervous system of the nematodes, resulting in their paralysis. Since 2015, it has been registered as an insecticide and nematicide that can also be used as a seed treatment to protect plants in the initial growing phase from PPNs and insects which attack root systems [107]. It can be stored for many months without losing its biological properties. Abamectin is known to have nematicidal activity against some PPNs such as the root-knot nematode Meloidogyne incognita [108-110], the root lesion nematode Pratylenchus penetrans [111], the reniform nematode Rotylenchulus reniformis [108,109], and the cyst nematodes Globodera pallida [112], Heterodera schachtii [113], H. avenae [114] and H. carotae [115]. In the EU its use is allowed against root-knot nematodes on tomato, 
eggplant, pepper and string-beans until 30 April 2022. The commercial product can be used after transplant only in plastic house conditions by drip irrigation systems at the rate $5 \mathrm{~L} /$ ha in a water volume of $10,000-20,000 \mathrm{~L} / \mathrm{ha}$.

Table 3 reports the main characteristics (formulation, concentration, application time, doses and number of applications) of bionematicides used in the C Zone of EU countries.

Table 3. List of bionematicides allowed for use in the C Zone of EU countries (approved for use under EC Reg. 2009/1107 according to BPDB: Bio-Pesticide Data Base).

\begin{tabular}{|c|c|c|c|c|c|c|}
\hline $\begin{array}{c}\text { Bionematicide } \\
\text { Based on }\end{array}$ & Name & Formulation & $\begin{array}{l}\text { Concentration a.i. }{ }^{1} \\
\text { (CFU/L or g/L) }\end{array}$ & $\begin{array}{l}\text { Application } \\
\text { Time }\end{array}$ & $\begin{array}{c}\text { Dose } \\
\text { (L or } \mathrm{Kg} / \mathrm{ha})\end{array}$ & $\begin{array}{c}\text { Number of } \\
\text { Applications during } \\
\text { the Crop Cycle }\end{array}$ \\
\hline \multirow[t]{2}{*}{ Fungi } & $\begin{array}{c}\text { Purpureocillium } \\
\text { lilacinum } \\
\text { strain } 251^{2}\end{array}$ & Liquid & $5.1 \times 10^{13}$ & $\begin{array}{l}\text { Transplant and } \\
\text { post-transplant }\end{array}$ & 0.75 & $3-4$ \\
\hline & $\begin{array}{c}\text { Pochonia } \\
\text { clamydosporia }^{3}\end{array}$ & Liquid & $10^{11}$ & $\begin{array}{l}\text { Transplant and } \\
\text { post-transplant }\end{array}$ & 2 & $2-3$ \\
\hline & Pasteuria penetrans & \multicolumn{5}{|c|}{ In advanced state of evaluation by the EU phytosanitary commission } \\
\hline Bacteria & $\begin{array}{c}\text { Bacillus firmus } \\
\text { (strain I 1582) }\end{array}$ & $\begin{array}{l}\text { Wettable } \\
\text { powder }\end{array}$ & $3.55 \times 10^{12}$ & $\begin{array}{c}\text { Before transplant } \\
\text { or sowing (A) } \\
\text { and after (B) }\end{array}$ & $\begin{array}{c}80(\mathrm{~A}) \text { or } \\
40+40(\mathrm{~B})\end{array}$ & 1 \\
\hline $\begin{array}{c}\text { Bacteria derived } \\
\text { product }\end{array}$ & Abamectin ${ }^{5}$ & Liquid & 20 & $\begin{array}{l}\text { Immediately after } \\
\text { transplant (first } \\
\text { application) }\end{array}$ & 5 & $\begin{array}{c}5 \text { (tomato) } \\
3 \text { (eggplant, pepper, } \\
\text { cucurbits) }\end{array}$ \\
\hline
\end{tabular}

${ }^{1}$ a.i. $=$ active ingredient; ${ }^{2}$ not allowed in Bulgaria and Malta; ${ }^{3}$ it is approved as biostimulant; it is a potential nematicide, the commercial formulation contains mycorrhizae of the genus Glomus and viable conidia of Arthrobotrys and Pochonia; ${ }^{4}$ not registered in Cyprus and Malta; ${ }^{5}$ it is approved as nematicide on protected crops in Bulgaria, Cyprus, Greece, Italy and Spain. Note: It is important to follow the instructions reported on the label of the product as they differ according to pest and crop. Information on concentration, application times, doses and number of applications are reported on the label of each commercial product.

\section{Plant Extracts}

In the EU, the following extracts are registered as active ingredients: garlic extract, clove oil, a mixture of oils based on thymol and geraniol and azadirachtin.

\subsection{Garlic Extract}

The extract is available both in granular (GR) and concentrated suspension (CS) for application at transplant or sowing at the rate of $20-25 \mathrm{Kg} / \mathrm{ha}$ (GR) or $2-4 \mathrm{~L} / \mathrm{ha}$ (CS) [116]. The active ingredient is not an ordinary garlic extract, it derives from a patented production process in which specific polysulfide compounds (molecules containing from 2 to 5 sulfur atoms, which represent the active ingredient of the formulation) are obtained from allicin (the substance causes the typical pungent smell of garlic). The garlic extract guarantees consistent and reproducible results. These polysulfide compounds act by contact and ingestion [117]. In the case of Solanaceae (tomato, eggplant, potato) and Cucurbitaceae (water melon and cantaloupe) it is recommended to apply the product in the transplant hole at least at $1 \mathrm{~g} /$ plant. The nematicidal action lasts 25-30 days. After the GR treatment, irrigation is advisable. The CS liquid formulation can be used at different stages of the crop cycle. The persistence of the product is about 14 days; therefore, after the first treatment, the CS product should be applied at 2 weeks intervals [118]. The formulations are effective against Meloidogyne spp., Tylenchus spp., Trichodorus spp., Longidorus spp., Pratylenchus spp., Xiphinema spp. and the cyst nematodes Globodera spp. and Heterodera spp. [119,120]. The use of the product is not allowed in Malta (Table 1).

\subsection{Clove Oil}

The commercial product is a natural formulation based on clove oil extracted from Eugenia caryophillata (better known as cloves) with high nematostatic and nematicidal action [121]. It acts mainly against eggs, by interfering with normal embryogenesis it drastically reduces the juveniles hatching rate [122]. The nematostatic action against the 
juveniles is also fundamental because the motile forms lose their motility and the ability to attack plant roots to complete their life cycle. It is important that the treatment must be carried out before the nematode activity inflicts severe damage on the vegetation state of the crops, in which case the treatment would be completely useless. Other treatments are recommended every 10 days after transplanting to maintain the crops in a healthy and vigorous condition. The a.i. contained in the commercial formulation is $200 \mathrm{~g} / \mathrm{L}$. The suggested doses are $5 \mathrm{~L} / 1000 \mathrm{~m}^{2}$ at transplant or sowing and 3-5 L/1000 $\mathrm{m}^{2}$ every 10 days after transplant or sowing for 5-6 treatments [123]. The product is authorized as nematicide only in Italy.

\subsection{Thymol and Geraniol Oils}

Essential oils (EOs) are complex mixtures of bioactive volatile compounds consisting of different compounds (terpenes and terpenoids, oxygenated terpenes, sesquiterpenes and phenylpropanoids) produced by the secondary metabolism of aromatic plants (Lamiaceae, Myrtaceae, and Umbelliferae) [124-126]. Nematicidal activities have been reported for plant EOs containing a mixture of thymol and geraniol oils against root-knot nematodes $[127,128]$. The product is used to protect Solanaceae and Cucurbitaceae from infection by nematode juveniles in the soil. Thymol and geraniol act against nematodes via different mechanisms. Due to their lipophilic nature, the primary mode of action of thymol and geraniol is their accumulation in cell membranes. It causes loss of integrity: a change in fatty acids and phospholipids composition and consequent lysis leads to releasing cellular substances and cell death. The product is characterized by no residues, no pre-harvest interval, favorable environmental profile, flexibility, easy application and, moreover, no development of resistance is expected. It is applied at transplant or sowing. Treatments must be repeated every 2 weeks by drip irrigation lines with a volume of water ranging between 10,000 and 20,000 L/ha at the dose of $9 \mathrm{~L} / \mathrm{ha}$ [129].

Table 4 reports the main characteristics (formulation, concentration, application time, doses and number of applications) of plant extracts used in the C Zone of EU countries.

Table 4. List of plant extracts allowed for use as nematicide in Southern EU countries.

\begin{tabular}{|c|c|c|c|c|c|c|}
\hline $\begin{array}{l}\text { Type of } \\
\text { Product }\end{array}$ & Name & Formulation & $\begin{array}{c}\text { Concentration a.i. }{ }^{1} \\
(\mathrm{~g} / \mathrm{L} \text { or } \mathrm{g} / \mathrm{Kg})\end{array}$ & Application Time & $\begin{array}{c}\text { Dose } \\
\text { (L or } \mathrm{Kg} / \mathrm{ha})\end{array}$ & $\begin{array}{c}\text { Number of } \\
\text { Applications during } \\
\text { the Crop Cycle }\end{array}$ \\
\hline Extract & Garlic $^{2}$ & $\begin{array}{c}\text { Granular (GR) } \\
\text { Concentrated } \\
\text { suspension (CS) }\end{array}$ & $\begin{array}{l}450(\mathrm{GR}) \\
999(\mathrm{CS})\end{array}$ & $\begin{array}{l}\text { Transplant or sowing (GR) } \\
\text { Pre- and post-transplant } \\
\text { or sowing (CS) }\end{array}$ & $\begin{array}{l}20-25(\mathrm{GR}) \\
2-4(\mathrm{CS})\end{array}$ & $\begin{array}{c}\text { Max } 6 \text { (for CS } \\
\text { formulation every } \\
2 \text { weeks) }\end{array}$ \\
\hline \multirow{2}{*}{ Oil } & Clove $^{3}$ & $\begin{array}{l}\text { Concentrated } \\
\text { emulsion }(\mathrm{CE})\end{array}$ & 203 & $\begin{array}{l}\text { Pre- and post-transplant } \\
\text { or sowing }\end{array}$ & $\begin{array}{c}50 \text { (pre) } \\
30-50 \text { (post) }\end{array}$ & Max 4 (every 10 days) \\
\hline & $\begin{array}{l}\text { Thymol and } \\
\text { geraniol }\end{array}$ & $\begin{array}{c}\text { Encapsulated } \\
\text { aqueous solution }\end{array}$ & $\begin{array}{l}41 \text { (thymol) }+ \\
121 \text { (geraniol) }\end{array}$ & $\begin{array}{l}\text { Pre- and post-transplant } \\
\text { or sowing }\end{array}$ & 9 & $\begin{array}{c}6 \\
\text { (every } 2 \text { weeks) }\end{array}$ \\
\hline
\end{tabular}

${ }^{1}$ a.i. = active ingredient; ${ }^{2}$ not allowed only in Malta; ${ }^{3}$ allowed only in Italy; ${ }^{4}$ not allowed in Bulgaria, Cyprus and Malta. Note: It is important to follow the instructions reported on the label product as they differ according to pest and crop. Information on concentration, application times, doses and number of applications are reported on the label of each commercial product.

\section{Conclusions}

The growing concern about the environment and human and animal health has led to a deep revision of the EU legislation on the application of pesticides in agriculture [130]. Their use has been strongly reduced and few chemical tools are available for farmers (fumigant and non-fumigant). In nematode control strategies, many nematicides have been forbidden because of their toxic effect on the environment (aldicarb, cadusafos, carbofuran, ethoprofos, chloropicrin, 1,3 dichloropropene, methyl bromide, and some others) [131-133]. The number of chemical nematicides on the market available for producers has significantly decreased in comparison to 15 years ago and vegetable producers are in trouble for adequate control measures against PPNs, although they use bio-nematicides or natural plant products. Considering that many effective fumigants have lost EU registration and effective 
technical solutions are not available, if not by national derogations [134], it is necessary to consider the approval of new products or fumigants with favorable eco-toxicological profiles and a zero Ozone Depletion Potential (ODP). In this context, it could be favorable to consider products that, in addition to the above reported nematological effect, also have fungicidal, insecticidal and herbicidal effects. The approval or registration of these potential products, and possibly their inclusion in the Integrated Pest Management (IPM) program guidelines, will be of interest for the EU vegetable industry. Among the ecofriendly methods of nematode control at zero environmental impact, there is the use of resistant cultivars, when they are available. It is important to highlight that the resistance in a crop is specific for each nematode genera and species [135]. Global climate changes are seeing a rise in new virulent populations capable of overcoming genetic resistances which might be broken also by higher temperature values $\left.\left(35-38^{\circ} \mathrm{C}\right)[136,137]\right)$. Resistant varieties don't always exist for the different crops and, when they exist, it is necessary to consider whether the relative products meet the needs of consumers. The use of soil organic amendments is also promising because they stimulate soil microorganisms able to decrease PPN populations and improve soil fertility and plant growth. Organic amendments might be particularly beneficial because they are natural materials, often produced by farmers at low or zero cost, from which nutrients and nematicidal substances are released gradually during the crop cycle. The use of biopesticides and plant extracts is environmentally friendly because these natural products are usually selective and destroy only targeted organisms. Moreover, their use in chemo-irrigation may significantly reduce production costs and allow farmers to maintain the profitability of crops and crop quality.

Author Contributions: Conceptualization, N.S. and A.K.; writing-original draft prep-aration, N.S. and S.R.; writing-review and editing, V.M., E.I.-S., I.T., P.V., A.B. and C.A.; bibliographic research, N.S., A.K., C.A. and P.V.; funding acquisition, N.S. All authors have read and agreed to the published version of the manuscript.

Funding: This research was supported by project DBA.AD004.039 CNR, Italy.

Institutional Review Board Statement: Not applicable.

Acknowledgments: We would like to thank Arben Myrta for his critical reading and suggestions during the revision of the manuscript.

Conflicts of Interest: The authors declare no conflict of interest.

\section{References}

1. Sasanelli, N.; Toderas, I.; Iurcu-Straistaru, E.; Rusu, S.; Migunova, V.; Konrat, A. Yield losses caused by plant parasitic nematodes graphical estimation. In Book of International Symposium "Functional Ecology of Animals"; National Book Chamber of R. Moldova, Ed.; Institute of Zoology: Chisinau, Moldova, 2018; pp. 319-329. ISBN 978-9975-3159-7-5.

2. Sikora, R.A.; Coyne, D.L.; Hallmann, J.; Timper, P. Reflections and Challenges: Nematology in Subtropical and Tropical Agriculture. In Plant Parasitic Nematodes in Subtropical and Tropical Agriculture, 3rd ed.; Sikora, R.A., Coyne, D.L., Hallmann, J., Timper, P., Eds.; CAB International: Boston, MA, USA, 2018; pp. 1-19.

3. Gheysen, G.; Jones, J.T. Molecular Aspects of Plant-Nematode Interactions. In Plant Nematology, 2nd ed.; Perry, R.N., Moens, M., Eds.; CAB International: Boston, MA, USA, 2013; pp. 274-300.

4. Sasanelli, N.; Ciccarese, F.; Papajova, I. Aphanocladium album by via sub-irrigation in the control of Pyrenochaeta lycopersici and Meloidogyne incognita on tomato in a plastic-house. Helminthologia 2008, 45, 137-142. [CrossRef]

5. Saeedizadeh, A.; Kheiri, A.; Zad, J.; Etebarian, H.R.; Bandani, A.R.; Nasiri, M.B. A study of interaction between Verticillium wilt Verticillium dahliae and root-knot nematode Meloidogyne javanica in olive cultivars. Commun. Agric. Appl. Biol. Sci. 2009, 74, 567-572. [PubMed]

6. Mai, W.F.; Abawi, G.S. Interactions among root-knot nematodes and Fusarium wilt fungi on host plants. Ann. Rev. Phytopatol. 1987, 25, 317-338. [CrossRef]

7. Seinhorst, J.W. The relationship between nematode density and damage to plants. Nematologica 1965, 11, 137-154. [CrossRef]

8. Seinhorst, J.W. Nematodes and growth of plants: Formulation of the nematode-plant system. In Root-Knot Nematodes (Meloidogyne Species) Systematics, Biology and Control; Lamberti, F., Taylor, C.E., Eds.; Academic Press: London, UK, 1979; pp. $231-256$.

9. Li, L.; Barry, T.; Mongar, K.; Wofford, P. Modeling methyl isothiocyanate soil flux and emission ratio form a field following a chemigation of metam-sodium. J. Environ. Qual. 2006, 35, 707-713. [CrossRef] [PubMed] 
10. Ingham, R.E.; Hamm, P.B.; David, N.L.; Wade, N.M. Control of Meloidogyne chitwoodi in Potato with Shank-injected Metam Sodium and other Nematicides. J. Nematol. 2007, 39, 161-168.

11. Stanton, J.M. Effect of Metham-Sodium on Potato Cyst Nematode; Report; Department of Agriculture and Food: Perth, Australia, 1986.

12. PPDB: Pesticide Properties DataBase. A to Z list of Pesticide Active Ingredients; University of Hertfordshire: Hatfield, UK, 2021.

13. Zamanzadeh, E.; Nabavikalat, S.M.; Norouzzadeh, S. Efficacy of sulfosulforon (Apyrus) and Metham Sodium (Vapam) herbicides on control of broomrape (Orobanche aeygptiaca) in tomato fields. J. Crop. Ecophysiol. 2011, 5, 67-81.

14. Ajwa, H.A.; Trout, T.; Mueller, S.; Wilhelm, S.; Nelson, S.D.; Soppe, R.; Shatley, D. Application of Alternative Fumigants Through Drip Irrigation Systems. Phytopatology 2002, 92, 1349-1355. [CrossRef]

15. Biles, C.L.; Lindsey, D.L.; Liddell, C.M. Control of Phytophthora root rot of chile peppers by irrigation practices and fungicides. Crop. Prot. 1992, 11, 225-228. [CrossRef]

16. Carlock, L.L.; Dotson, T.A. Metam-Sodium (Chapter 107). In Hayes's Handbook of Pesticide Toxicology, 3rd ed.; Academic Press: Cambridge, UK, 2010; pp. 2293-2306. [CrossRef]

17. Khatri, K.; Vallad, G.; Peres, N.; Desaegaer, J.; Regmi, H. Efficacy of metam potassium on Fusarium oxysporum, Macrophomina phaseolina, Meloidogyne javanica, and seven weed species in microcosm experiments. Pest. Manag. Sci. 2021, 77, 869-876. [CrossRef] [PubMed]

18. Gamliel, A.; Katan, J. Disinfestation. In Encyclopedia of Soils in the Environment; Hillel, D., Ed.; Elsevier: Amsterdam, The Netherlands, 2005; pp. 394-400. [CrossRef]

19. Philis, J. Effect of D-D, EDB and Dazomet on Potato Cyst Nematode Control in Clay Soils of Cyprus. Nematol. Medit. 1978, 6, 77-81.

20. Patel, N.D.; Patel, A.D. Management of Root-Knot Nematodes (Meloidogyne spp.) using different Chemicals in Tomato Nursery. Int. J. Curr. Microbiol. App. Sci. 2019, 8, 2047-2051. [CrossRef]

21. Lamberti, F.; Sasanelli, N.; D'Addabbo, T.; Carella, A. Translocation and persistance of fenamiphos in the control of root-knot nematodes. Meded. Fac. Landbouwkd. Toegep. Biol. Wet. Univ. Gent 2000, 65, 463-469.

22. European Food Safety Authority. Peer review of the pesticide risk assessment of the active substance fenamiphos. EFSA J. 2019, $17,5557$.

23. Johnson, W.A.; Young, J.R. Efficacy of Fenamiphos Formulations Applied through Irrigation for Control of Meloidogyne incognita on Squash. J. Nematol. 1994, 26, 697-700.

24. Chabrier, C.; Hubervic, J.; Quénéhervé, P. Evaluation of Fosthiazate (Nemathorin 10 G) for the control of nematodes in banana fields in Martinique. Nematropica 2002, 32, 137-147.

25. PubChem. National Library of Medicine; National Center for Biotechnology Information: Bethesda, MD, USA, 2019. Available online: https:/ / pubchem.ncbi.nlm.nih.gov /\#query=Oxamyl (accessed on 20 June 2021).

26. Rousidou, C.; Karaiskos, D.; Myti, D.; Karanasios, E.; Karas, P.A.; Tourna, M.; Tzortzakakis, E.A.; Karpouzas, D.G. Distribution and function of carbamate hydrolase genes cehA and mcd in soils: The distinct role of soil pH. FEMS Microbiol. Ecol. 2017, 93. [CrossRef]

27. Kennedy, J.L., Jr. Acute toxicity studies with oxamyl. Fundam. Appl. Toxicol. 1986, 6, 423-429. [CrossRef]

28. Lamberti, F.; Sasanelli, N.; D'Addabbo, T.; Carella, A. Study on the nematicide translocation and persistence of oxamyl. Inf. Fitopatol. 2003, 7, 57-59. (In Italian)

29. Du Pont de Nemours (It). Label of Vydate 10L. Label Authorized by Executive Decree of 13 June 2015 and Modified According to art. 7, Paragraph 1, Presidential Decree n. 55/2012. 2015. Valid from 22 June 2018. Available online: https: / / www.corteva.it/ content/dam/dpagco/corteva/eu/it/it/files/cp/DF_Vydate_10_L-label.pdf (accessed on 20 June 2021). (In Italian).

30. EFSA. Conclusion on the peer review of the pesticide risk assessment of the active substance fluopyram. EFSA J. $2013,11,3052$.

31. Burns, A.R.; Luciani, G.M.; Musso, G.; Bagg, R.; Yeo, M.; Zhang, Y.; Rajendran, L.; Glavin, J.; Hunter, R.; Redman, E.; et al. Caenorhabditis elegans is a useful model for anthelmintic discovery. Nat. Commun. 2015, 6, 7485. [CrossRef] [PubMed]

32. Oka, Y. From Old-Generation to Next-Generation Nematicides. Agronomy 2020, 10, 1387. [CrossRef]

33. Faske, T.R.; Hurd, K. Sensivity of Meloidogyne incognita and Rotylenchulus reniformis to Fluopyram. J. Nematol. 2015, 47, 316-321.

34. Storelli, A.; Keiser, A.; Eder, R.; Jenni, S.; Kiewnick, S. Evaluation of fluopyram for the control of Ditylenchus dipsaci in sugar beet. J. Nematol. 2020, 52, 1-10. [CrossRef] [PubMed]

35. Beeman, A.Q.; Tylka, G.L. Assessing the effects of ILeVO and VOTiVO seed treatments on reproduction, hatching, motility, and root penetration of the soybean cyst nematode, Heterodera glycines. Plant Dis. 2018, 102, 107-113. [CrossRef] [PubMed]

36. Beeman, A.Q.; Njus, Z.L.; Pandey, S.; Tylka, G. Effects of ILeVO and VOTiVO on root penetration and behavior of the soybean cyst nematode, Heterodera glycines. Plant Dis. 2019, 103, 392-397. [CrossRef]

37. Kandel, Y.R.; Wise, K.A.; Bradley, C.A.; Chilvers, M.I.; Byrne, A.M.; Tenuta, A.U.; Faghihi, J.; Wiggs, S.N.; Mueller, D.S. Effect of soybean cyst nematode resistance source and seed treatment on population densities of Heterodera glycines, sudden death syndrome, and yield of soybean. Plant Dis. 2017, 101, 2137-2143. [CrossRef] [PubMed]

38. Roth, M.G.; Jacobs, J.L.; Napieralski, S.; Byrne, A.M.; Stou er-Hopkins, A.; Warner, F.; Chilvers, M.I. Fluopyram suppresses population densities of Heterodera glycines in field and greenhouse studies in Michigan. Plant Dis. 2020, 104, 1305-1311. [CrossRef]

39. Hawk, T. The Effects of Seed-Applied Fluopyram on Root Penetration and Development of Meloidogyne incognita on Cotton and Soybean. Ph.D. Theis, University of Arkansas, Fayetteville, AR, USA, 2019; p. 47.

40. Li, J.; Wang, C.; Bangash, S.H.; Lin, H.; Zeng, D.; Tang, W. Efficacy of fluopyram applied by chemigation on controlling eggplant root-knot nematodes (Meloidogyne spp.) and its effects on soil properties. PLoS ONE 2020, 15, e0235423. [CrossRef] 
41. Chitwood, D. Phytochemical Based Strategies for Nematode Control. Ann. Rev. Phytopathol. 2002, 40, 221-249. [CrossRef]

42. Gowen, S.R. Chemical control of nematodes: Efficiency and side-effects. FAO Plant Prod. Prot. Pap. 1997, 144, 59-65.

43. Nusbaum, C.J.; Ferris, H. The Role of Cropping Systems in Nematode Population Management. Ann. Rev. Phytopathol. 1973, 11, 423-440. [CrossRef]

44. Vovlas, A.; Santoro, S.; Sasanelli, N. Weeds as alternative hosts for plant parasitic nematodes and their ability to maintain nematode populations larger than the tolerance limit for the main crop. In Proceedings of the 7th International Weed Science Congress, Prague, Czech Republic, 19-25 June 2016.

45. Roberts, P.A.; Thomasom, I.J. Sugarbeet pest management nematodes. (University of California, Division of Agricultural Science, Los Angeles, LA, USA), Special Publication 3272, 1981, 30. Available online: https:/ / books.google.it/books?hl=en\&lr=\&id=a_cz_ u40P6AC\&oi=fnd\&pg=PA3\&dq=Sugar+Beet+pest+management+nematodes\&ots (accessed on 20 June 2021).

46. Curto, G.; Di Silvestro, D. Fight. Chapter 10.6.1—Crop rotations. In General and Applied Plant Nematology (Nematologia Agraria Generale ed Applicata); Italian Society of Nematology: Florence, Italy, 2014; pp. 199-202. Available online: http:/ / www.nematologia. it/index.php?option=com_content\&view=article\&id=122:informazioni-sul-libro\&catid=14:sample-data-articles (accessed on 20 June 2021). (In Italian)

47. Zhong, S.; Zeng, H.C.; Jin, Z.Q. Response of soil nematode community composition and diversity to different crop rotations and tillage in the tropics. App. Soil Ecol. 2016, 107, 134-143. [CrossRef]

48. Brennan, R.J.B.; Glaze-Corcoran, S.; Wick, R.; Hashemi, M. Biofumigation: An alternative strategy for the control of plant parasitic nematodes. J Integr Agric. 2020, 19, 1680-1690. [CrossRef]

49. Thangstad, O.P.; Evjen, K.; Bones, A. Immunogold-EM localization of myrosinase in Brassicaceae. Protoplasma 1991, 161, 85-93. [CrossRef]

50. Caboni, P.; Sarais, G.; Aissani, N.; Tocco, G.; Sasanelli, N.; Liori, B.; Carta, A.; Angioni, A. Nematicidal activity of 2Thiophenecarboxaaldehyde and Methylisothiocyanate from Caper (Capparis spinosa) against Meloidogyne incognita. J. Agric. Food Chem. 2012, 60, 7345-7351. [CrossRef]

51. Lazzeri, L.; Curto, G.; Dallavalle, E.; D’Avino, L.; Malaguti, L.; Santi, R.; Patalano, G. Nematicidal efficacy of biofumigation by defatted Brassicaceae meal for control of Meloidogyne incognita (Kofoid\& White) Chitw. on a full field zucchini crop. J. Sust. Agric. 2009, 33, 349-358.

52. D'Addabbo, T.; De Mastro, G.; Sasanelli, N.; Di Stefano, A.; Omidbaigi, R. Suppressive action of different crociferous crops on the root-knot nematode Meloidogyne incognita. Agroindustria 2004, 3, 379-380.

53. Buskov, S.; Serra, B.; Rosa, E.; Sorensen, H.; Sorensen, J.C. Effect of intact glucosinolates and products from glucosinolates in myrosinase-catalyzed hydrolysys on the potato cyst nematode (Globodera rostrochiensis Woll.). J. Agric. Food Chem. 2002, 50, 690-695. [CrossRef]

54. Adediran, J.A.; Adegbite, A.A.; Akinlosotu, T.A.; Agbaje, G.O.; Taiwo, L.B.; Owolade, O.F.; Oluwatosin, G.A. Evaluation of fallow and cover crops for nematode suppression in three agro-ecologies of south western Nigeria. Afric. J. Biotechnol. 2005, 4, 1034-1039.

55. Gadhave, A. A Short Review on Microemulsion and its application in extraction of vegetable oil. Int. J. Res. Eng. Technol. 2014, 3, 147-158. [CrossRef]

56. Westerdahl, B.B. Evaluation of trap cropping for management of root-knot nematode on annual crops. Acta Hortic. 2020, 1270, 141-146. [CrossRef]

57. Sacchi, S.; Torrini, G.; Marianelli, L.; Mazza, G.; Fumagalli, A.; Cavagna, B.; Ciampitti, M.; Roversi, P.F. Control of Meloidogyne graminicola a Root-Knot Nematode Using Rice Plants as Trap Crops: Preliminary Results. Agriculture 2021, 11, 37. [CrossRef]

58. Commission Implementing Regulation (EU) 2019/2164. Amending Regulation (EC) No 889/2008 Laying Down Detailed Rules for the Implementation of Council Regulation (EC) $N^{\circ} 834 / 2007$ on Organic Production and Labelling of Organic Products with Regard to Organic Production, Labelling And control. Off. J. Eur. Union 2019. Available online: https:/ / eur-lex.europa.eu/legalcontent/EN/ALL/?uri=uriserv:OJ.L_.2019.328.01.0061.01.ENG (accessed on 20 June 2021).

59. Renčo, M. Organic amendments of soil as useful tools of plant parasitic nematodes control. Helminthologia 2013, 50, 3-14. [CrossRef]

60. D'Addabbo, T.; Fontanazza, G.; Lamberti, F.; Sasanelli, N.; Patumi, M. The suppressive effect of soil amendments with olive residues on Meloidogyne incognita. Nematol. Medit. 1997, 25, 195-198.

61. D'Addabbo, T.; Sasanelli, N. The suppression of Meloidogyne incognita on tomato by grape pomace soil amendments. Nematol. Medit. 1998, 26, 145-149.

62. D'Addabbo, T.; Sasanelli, N.; Lamberti, F.; Greco, P.; Carella, A. Olive pomace and chicken manure amendments for control of Meloidogyne incognita over two crop cycles. Nematropica 2003, 33, 1-7.

63. Sasanelli, N.; Ferri, D.; Convertini, G.; D'Addabbo, T. Nematicidal and agronomical effects of composted olive pomace amendments. In Proceedings of the 12th Congress of the Mediterranean Phytopathological Union, Rhodes Island, Greece, 11-15 June 2006; pp. 565-567.

64. Renčo, M.; Sasanelli, N.; Salamun, P. The effect of two compost soil amendments, based on municipal green and penicillin production wastes, on plant parasitic nematodes. Helminthologia 2009, 46, 190-197. [CrossRef]

65. Renčo, M.; Sasanelli, N.; D’Addabbo, T.; Papajova, I. Soil nematode community changes associated with compost amendments. Nematology 2010, 12, 681-692. [CrossRef] 
66. Abdelaym, E.A.; Erriquens, F.; Sasanelli, N.; Ceglie, F.G.; Zaccone, G.; Miano, T.; Cocozza, C. Effects of several amendments on organic melon growth and production, Meloidogyne incognita population and soil properties. Sci. Hortic. 2014, 180, 156-160. [CrossRef]

67. D'Addabbo, T.; Migunova, V.; Renčo, M.; Sasanelli, N. Suppressiveness of soil amendments with pelleted plant materials on the root-knot nematode Meloidogyne incognita. Helminthologia 2020, 57, 376-383. [CrossRef]

68. Cayuela, M.L.; Millner, P.D.; Meyer, S.L.F.; Roig, A. Potential of olive mill wasteand compost as biobased pesticides against weeds, fungi and nematodes. Sci. Total Environ. 2008, 399, 11-18. [CrossRef]

69. Galper, S.; Cohn, E.; Spiegel, Y.; Chet, I. A collagenolytic fungus, Cunninghamella elegans, for biological control of plant parasitic nematodes. J. Nematol. 1991, 23, 269-274.

70. Gooday, G.W. The ecology of chitin degradation. In Advances in Microbial Ecology; Marshall, K.C., Ed.; Plenum Press: New York, NY, USA, 1990; Volume 2, pp. 387-430.

71. Lamers, J.G.; Runia, W.T.; Molendijk, L.P.G.; Bleeker, P.O. Perspectives of Anaerobic Soil Disinfestation. Acta Hort. 2010, 883, 277-283. [CrossRef]

72. Runia, W.T.; Molendijk, L.P.G. Physical Methods for Soil Disinfestation in Intensive Agriculture: Old Methods and New Approaches. Acta Hort. 2010, 833, 249-258. [CrossRef]

73. Katan, J.; Greenberger, A.; Alon, H.; Grinstein, A. Solar heating by polyethylene mulching for the control of diseases caused by soil-borne pathogens. Phytopathology 1976, 66, 683-688. [CrossRef]

74. Katan, J. Soil solarization. In Innovative Approaches to Plant Disease Control; Chet, I., Ed.; John Wiley and Sons: New York, NY, USA, 1987; pp. 77-105.

75. Porter, I.J.; Merriman, P.R. Effect of solarization of soil on nematode and fungal pathogens at two siets in Victoria. Soil Biol. Biochem. 1983, 15, 39-44. [CrossRef]

76. Stepleton, J.J.; De Vay, J.E. Response of phytoparasitic and free-living nematodes to soil solarization and 1,3 dichloropropene in California. Phytopathology 1983, 73, 1429-1436. [CrossRef]

77. La Mondia, J.A.; Brodie, B.B. Control of Globodera rostochiensis by solar heat. Plant Dis. 1984, 68, 474-476. [CrossRef]

78. Greco, N.; Brandonisio, A.; Elia, F. Control of Ditylenchus dipsaci, Heterodera carotae and Meloidogyne javanica by solarization. Nematol. Medit. 1985, 13, 191-197.

79. Barbercheck, M.E.; Von Broenbsen, S.L. Effect of soil solarization on plant-parasitic nematodes and Phytophtora cinnamon in South Africa. Plant Dis. 1986, 70, 945-950. [CrossRef]

80. Candido, V.; D’Addabbo, T.; Basile, M.; Castronuovo, D.; Miccolis, V. Greenhouse soil solarization: Effect on weeds, nematodes and yield of tomato and melon. Agron. Sust. Develop. 2008, 28, 221-230. [CrossRef]

81. Greco, N.; D'Addabbo, T.; Sasanelli, N.; Seinhorst, J.W.; Stea, V.; Brandonisio, A. Effects of temperature and length of exposure on the mortality of the carrot cyst nematode, Heterodera carotae. Int. J. Pest. Manag. 1998, 44, 99-107. [CrossRef]

82. Greco, N.; Brandonisio, A.; D'Angelico, A. Control of the potato cyst nematode, Globodera rostochiensis, with soil solarization and nematicides. Nematol. Medit. 2000, 28, 93-99.

83. Di Vito, M.; Greco, N.; Saxena, M.C. Effectiveness of soil solarization for control of Heterodera ciceri and Pratylenchus thornei on chickpea on in Syria. Nematol. Medit. 1991, 19, 109-111.

84. D'Addabbo, T.; Sasanelli, N.; Greco, N.; Stea, V.; Brandonisio, A. Effect of Water, Soil Temperatures, and Exposure Times on the Survival of the Sugar Beet Cyst Nematode: Heterodera schachtii. Phytopathology 2005, 95, 339-344. [CrossRef]

85. Gaur, H.S.; Dhingra, A. Management of Meloidogyne incognita and Rotylenchulus reniformis in nursery-beds by soil solarization and organic soil amendment. Rev. Nematol. 1991, 14, 189-195.

86. Sasanelli, N.; Greco, N. Formulation of a model to relate nematode populations with exposure times to a range of temperatures Acta Hort. 2000, 532, 131-135. [CrossRef]

87. Oka, Y.; Shapira, N.; Finec, P. Control of root-knot nematodes in organic farming systems by organic amendments and soil solarization. Crop Prot. 2007, 26, 1556-1565. [CrossRef]

88. Moura, L.; Queiroz, I.; Mourao, I.; Brito, L.M. Effectiveness of soil solarization and biofumigation for the control of corky root and root-knot nematode Meloidogyne spp. on tomato. Acta Hort. 2012, 933, 399-406. [CrossRef]

89. Butler, D.M.; Kokalis-Burelle, N.; Muramoto, J.; Shennan, C.; McColluma, G.; Rosskopfa, E.N. Impact of anaerobic soil disinfestation combined with soil solarization on plant-parasitic nematodes and introduced inoculum of soilborne plant pathogens in raised-bed vegetable production. Crop Prot. 2012, 39, 33-40. [CrossRef]

90. Kiewnick, S.; Sikora, R.A. Biological control of the root-knot nematode Meloidogyne incognita by Paecilomyces lilacinus strain 251. Biol. Control 2006, 38, 179-186. [CrossRef]

91. Castillo, J.D.; Lawrence, K.S.; Kloepper, J.W. Biocontrol of the Reniform Nematode by Bacillus firmus GB-126 and Paecilomyces lilacinus 251 on Cotton. Plant Dis. 2013, 97, 967-976. [CrossRef]

92. Bayer CropScience (It). Label of BioAct Prime DC. Label authorized by Italian Healthy Ministery, Decree $\mathrm{N}^{\circ} 17118$ of 27 February 2019. Available online: https://www.cropscience.bayer.it/-/media/prodotti/bioact-prime-dc/etichetta_bioact-prime-dc.pdf (accessed on 20 June 2021). (In Italian).

93. Manzanilla-Lopez, R.H.; Esteves, I.; Finetti-Sialer, M.M.; Hirsch, P.R.; Ward, E.; Devonshire, J.; Hidalgo-Diaz, L. Pochonia chlamydosporia: Advances and challenges to improve its performance as a biological control agent of sedentary endo-parasitic nematodes. $J$. Nematol. 2013, 45, 1-7. 
94. Rosso, L.C.; Colagiero, M.; Salatino, N.; Ciancio, A. Effect of trophic conditions on gene expression of Pochonia chlamydosporia. Ann. Appl. Biol. 2014, 164, 232-243. [CrossRef]

95. Ciancio, A.; Colagiero, M.; Ferrara, M.; Nigro, F.; Pentimone, I.; Rosso, L.C. Transcriptome changes in tomato roots during colonization by the endophytic fungus Pochonia chlamydosporia. Abstr. In Proceedings of the 5th Congress, Federation of the European Microbiologists Societies (FEMS), Leipzig, Germany, 21-25 July 2013.

96. Zavala-Gonzales, E.A.; Escudero, N.; Lopez-Moya, F.; Aranda-Martinez, A.; Exposito, A.; Ricaño-Rodríguez, J.; Naranjo-Ortiz, M.A.; Ramírez-Lepe, M.; Lopez-Llorca, L.V. Some isolates of the nematophagous fungus Pochonia chlamydosporia promote root growth and reduce flowering time of tomato. Ann. App. Biol. 2015, 166, 472-483. [CrossRef]

97. Sellitto, V.M.; Curto, G.; Dallavalle, E.; Ciancio, A.; Colagiero, M.; Pietrantonio, L.; Bireescu, G.; Stoleru, V.; Storari, M. Effect of Pochonia chlamydosporia-based formulates on the regulation of root-knot nematodes and plant growth response. Front Life Sci. 2016, 9, 1-5. [CrossRef]

98. Bishop, A.H.; Gowen, S.R.; Pembroke, B.; Trotter, J.R. Morphological and molecular characteristics of a new species of Pasteuria parasitic on Meloidogyne ardenensis. J. Invert. Pathol. 2007, 96, 23-33. [CrossRef] [PubMed]

99. Starr, M.P.; Sayre, R.M. Pasteuria thorneii sp. nov. and Pasteuria penetrans sensu stricto emend. mycelial and endospore-forming bacteria parasitic, respectively, on plant-parasitic nematodes of the genera Pratylenchus and Meloidogyne. In Annales de l'Institut Pasteur/Microbiologie; Elsevier: Paris, France, 1988; Volume 139, pp. 11-31.

100. Atibalentja, N.; Jakstys, B.P.; Noel, G.R. Life cycle, ultrastructure, and host specificity of the North American isolate of Pasteuria that parasitizes the soybean cyst nematode, Heterodera glycines. J. Nematol. 2004, 36, 171-180.

101. EFSA. Peer review of the pesticide risk assessment of the active substance Pasteuria nishizawae Pn1. EFSA J. 2018, 5159. [CrossRef]

102. Ghahremani, Z.; Escudero, N.; Beltrán-Anadón, D.; Saus, E.; Cunquero, M.; Andilla, J.; Loza-Alvarez, P.; Gabaldón, T.; Sorribas, F.J. Bacillus firmus Strain I-1582, a Nematode Antagonist by Itself and Through the Plant. Front Plant. Sci. 2020, 10, 796. [CrossRef]

103. Geng, C.; Nie, X.; Tang, Z.; Yuyang Zhang, Y.; Lin, J.; Ming Sun, M.; Peng, D. A novel serine protease, Sep1, from Bacillus firmus DS-1 has nematicidal activity and degrades multiple intestinal-associated nematode proteins. Sci. Reposts 2016, 6, 1-12. [CrossRef]

104. Bayer CropScience (It). Label of Flocter. Label authorized by Italian Healthy Ministery, Decree $\mathrm{N}^{\circ} 15841$ of 30 June 2013 . Available online: https: / / www.salute.gov.it/fitosanitariwsWeb_new /EtichettaServlet?id=27296 (accessed on 20 June 2021).

105. European Food Safety Authority. Conclusion on the peer review of the pesticide risk assessment of the active substance Bacillus firmus I-1582. EFSA J. 2012, 10, 2868. Available online: https://www.efsa.europa.eu/en/efsajournal/pub/2868 (accessed on 20 June 2021). [CrossRef]

106. Jansson, R.K.; Dybas, R.A. Avermectins: Biochemical mode of action, biological activity and agricultural importance. In Insecticides with Novel Modes of Action: Mechanism and Application; Chapter 9; Ishaaya, I., Ed.; Springer: Berlin/Heidelberg, Germany, 1998; pp. $152-170$.

107. Khalil, M.S. Abamectin and Azadirachtin as Eco-friendly Promising Biorational Tools in Integrated Nematodes Management Programs. J. Plant Pathol. Microb. 2013, 4, 174. [CrossRef]

108. Faske, T.R.; Starr, J.L. Sensitivity of Meloidogyne incognita and Rotylenchulus reniformis to Abamectin. J. Nematol. 2006, 38, 240-244. Available online: http:/ / www.ncbi.nlm.nih.gov/pubmed/19259453 (accessed on 20 June 2021).

109. Jayakumar, J. Bio-efficacy of Streptomyces avermitilis culture filtrates against root-knot nematode, Meloidogyne incognita and reniform nematodes, Rotylenchulus reniformis. J. Agric. Sci. 2009, 22, 567-571.

110. Toderas, I.; Rusu, S.; Iurcu-Straistaru, E.; Erhan, D.; Poiras, N.; Bivol, A.; Sasanelli, N.; Rusu, V. Control of the root-knot nematode Meloidogyne incognita by Ivomec containing an exametabolite of Streptomyces avermitilis. In Proceedings of the 9th International Conference of Zoologists, Chisinau, Moldova, 12-13 October 2016; pp. 176-177.

111. Samac, D.; Kinkel, L.L. Suppression of the root-lesion nematode (Pratylenchus penetrans) in alfalfa (Medicago sativa) by Streptomyces spp. Plant Soil 2001, 235, 35-44. [CrossRef]

112. Sasanelli, N.; Toderas, I.; Veronico, P.; Iurcu-Straistaru, E.; Rusu, S.; Melillo, M.T.; Caboni, P. Abamectin Efficacy on the Potato Cyst Nematode Globodera pallida. Plants 2020, 9, 12. [CrossRef]

113. Cabrera, J.A.; Kiewnick, S.; Grimm, C.; Dababat, A.A.; Sikora, R.A. Efficacy of abamectin seed treatment on Pratylenchus zeae, Meloidogyne incognita and Heterodera schachtii. J. Plant Dis. Prot. 2009, 116, 124-128. [CrossRef]

114. Zhang, D.; Wang, H.; Ji, X.; Wang, K.; Wang, D.; Qiao, K. Effect of Abamectin on the Cereal Cyst Nematode (CCN, Heterodera avenae) and Wheat Yield. Plant Dis. 2017, 101, 973-976. [CrossRef]

115. Toderas, I.; Erhan, D.; Rusu, S.; Iurcu-Straistaru, E.; Bivol, A.; Sasanelli, N.; Toderas, L. In vitro effect of abamectin on the carrot cyst nematode Heterodera carotae. In Proceedings of the 9th International Conference of Zoologists, Chisinau, Moldova, 12-13 October 2016; pp. 174-175.

116. Ladurner, E.; Benuzzi, M.; Fiorentini, F.; Lucchi, A. Efficacy of NemGuard ${ }^{\circledR}$ Granules, a new nematicide based on garlic extract for the control of root-knot nematodes on horticultural crops. Acts Phytopathol. Days 2014, 1, 301-308.

117. Eder, R.; Consoli, E.; Krauss, J.; Dahlin, P. Polysulfides Applied as Formulated Garlic Extract to Protect Tomato Plants against the Root-Knot Nematode Meloidogyne incognita. Plants 2021, 10, 394. [CrossRef]

118. ECOspray Ltd. Label of Nemguard. Label authorized by Italian Healthy Ministery, Decree $\mathrm{N}^{\circ} 116742$, 28 January 2020. Available online: https://www.biogard.it/wp-content/uploads/2020/03/NEMGUARD_SC-1.pdf (accessed on 20 June 2021).

119. Andrés, M.F.; González-Coloma, A.; Sanz, J.; Burillo, J.; Sainz, P. Nematicidal activity of essential oils: A review. Phytochem. Rev. 2012, 11, 371-390. [CrossRef] 
120. Jardim, I.N.; Oliveira, D.F.; Campos, V.P.; Silva, G.H.; Souza, P.E. Garlic essential oil reduces the population of Meloidogyne incognita in tomato plants. Europ. J. Plant Pathol. 2020, 157, 197-209. [CrossRef]

121. Meyer, S.L.F.; Lakshman, D.K.; Zasada, I.A.; Vinyard, B.T.; Chitwood, D.J. Dose-response effects of clove oil from Syzygium aromaticum on the root-knot nematode Meloidogyne incognita. Pest Manag. Sci. 2008, 64, 223-229. [CrossRef]

122. Djiwanti, S.R.; Supriadi, W.; Wiratno, W. Effectiveness of some clove and citronella oil based-pesticide formulas against root-knot nematode on ginger. IOP Conf. Ser. Earth Environ. Sci. 2019, 250, 012090. [CrossRef]

123. Xeda Italia. Label of Eugenio. Registration $N^{\circ}$ 17616-5 June 2020. Available online: http:/ / www.xeda.it/it/difesa-protezione/9/ eugenio/X/17224 (accessed on 20 June 2021).

124. Bakkali, F.; Averbeck, S.; Averbeck, D.; Idaomar, M. Biological effects of essential oils-A review. Food Chem. Toxicol. 2008, 46, 446-475. [CrossRef] [PubMed]

125. Avato, P.; Laquale, S.; Argentieri, M.P.; Lamiri, A.; Radicci, V.; D'Addabbo, T. Nematicidal activity of essential oils from aromatic plants of Morocco. J. Pest. Sci. 2017, 90, 711-722. [CrossRef]

126. D'Addabbo, T.; Argentieri, M.P.; Laquale, S.; Candido, V.; Avato, P. Relationship between Chemical Compisition and Nematicidal Activity of Different Essential Oils. Plants 2020, 9, 1546. [CrossRef] [PubMed]

127. Sasanelli, N.; Anton, A.; Takacs, T.; D'Addabbo, T.; Biro, I.; Malov, X. Influence of arbuscular mychorrizal fungi on the nematicidal properties of leaf extracts of Thymus vulgaris L. Helminthologia 2009, 46, 230-240. [CrossRef]

128. Mattarelli, P.; Epifano, F.; Minardi, P.; Di Vito, M.; Modesto, M.; Barbanti, L.; Bellardi, M.G. Chemical composition and antimicrobial activity of essential oils from aerial parts of Monarda didyma and Monarda fistulosa cultivated in Italy. J. Essent. Oil Bear. Plants 2017, 20, 76-86. [CrossRef]

129. Eastman Italia. Label of Cedroz. Label Authorized by Italian Healthy Ministery, Decree $\mathrm{N}^{\circ} 117415,3$ April 2019. Available online: https:/ / mccaa.org.mt/media/3881/cedroz.pdf (accessed on 20 June 2021).

130. Forghani, F.; Hajihassani, A. Recent Advances in the Development of Environmentally Benign Treatments to Control Root-Knot Nematodes. Front. Plant Sci. 2020, 11, 1125. [CrossRef]

131. Lamberti, F.; Minuto, A.; Caroppo, S.; Sasanelli, N.; Ambrogioni, L.; D’Addabbo, T.; Carella, A.; Tescari, E.; Coiro, M.I.; Spotti, C.A. The EC formulation of the 1,3 dichloropropene as an alternative to methyl bromyde in the control of root-knot nematodes. In Proceedings of the Annual International Research Conference on Methyl Bromide Alternatives and Emissions Reductions, San Diego, CA, USA, 5-9 November 2001.

132. Sasanelli, N.; D'Aloisio, V.; Basile, M.; Rana, G.L. Control of Ditylenchus dipsaci on Onion by Chemical Treatments with Cadusafos, Fenamiphos and Aldicarb. Afro Asian J. Nematol. 1995, 5, $24-27$.

133. European Food Safety Authority (EFSA); Anastassiadou, M.; Auteri, M.A.D.; Brancato, A.; Bura, L.; Carrasco Cabrera, L.; Chaideftou, E.; Chiusolo, A.; Court Marques, D.; Crivellente, F.; et al. Review of the pesticide risk assessment of the active substance chloropicrin. EFSA J. 2020, 18, 6028. [CrossRef]

134. Greco, N.; Lopez-Aranda, J.M.; Maccarini, C.A.; Saporiti, M.; de Tommaso, M.; Myrta, A. Sustainability of European vegetables and strawberry production in relation to fumigation practices in EU. Acta Hort. 2020, 1270. [CrossRef]

135. Goggin, F.L.; Lingling Jia, L.; Shah, G.; Hebert, S.; Valerie, M.; Williamson, V.M.; Ullman, D.E. Heterologous Expression of the Mi-1.2 Gene from Tomato Confers Resistance Against Nematodes but Not Aphids. MPMI 2006, 19, 383-388. Available online: https: / / pubmed.ncbi.nlm.nih.gov/16610741/ (accessed on 14 February 2007). [CrossRef]

136. Chen, S. Dynamics of Population Density and Virulence Phenotype of the Soybean Cyst Nematode as Influenced by Resistance Source Sequence and Tillage. Plant Disease 2020, 104, 2111-2122. [CrossRef]

137. El-Sappah, A.H.; Islam, M.M.; El-awady, H.H.; Yan, S.; Qi, S.; Liu, J.; Cheng, G.; Liang, Y. Tomato Natural Resistance Genes in Controlling the Root-Knot Nematode. Genes 2019, 10, 925. [CrossRef] [PubMed] 